\title{
Diversity and biogeographic affinities of Apionidae (Coleoptera: Curculionoidea) along an altitudinal gradient in EI Cielo Biosphere Reserve of northeastern Mexico
}

\section{Diversidad y afinidades biogeográficas de Apionidae (Coleoptera: Curculionoidea) a lo largo de un gradiente altitudinal en la Reserva de la Biosfera El Cielo en el noreste de México}

\author{
Robert W. Jones $^{1 \otimes}$, Santiago Niño-Maldonado² y Jesús Luna-Cozar ${ }^{3}$ \\ ${ }^{1}$ Facultad de Ciencias Naturales, Universidad Autónoma de Querétaro, Avenida de las Ciencias, s/n, 76230 Juriquilla, Querétaro, México. \\ ${ }^{2}$ Unidad Académica Multidisciplinaria Agronomía y Ciencias, Universidad Autónoma de Tamaulipas, Centro Universitario, 87149 Ciudad Victoria, \\ Tamaulipas, México. \\ ${ }^{3}$ El Colegio de la Frontera Sur, Carr. Panamericana y Periférico Sur s/n, 29290 San Cristóbal de las Casas, Chiapas, México. \\ \rjones@uaq.mx
}

\begin{abstract}
The altitudinal and temporal distributions of species in the family Apionidae (Coleoptera: Curculionoidea) were studied in El Cielo Biosphere Reserve (ECBR) in the state of Tamaulipas, northeastern Mexico. Species richness, diversity and abundance were recorded along an altitudinal gradient, from 100 to $1900 \mathrm{~m}$. A total of 571 individuals of 51 species were collected, representing 30\% of the total species of Apionidae recorded for Mexico. Richness estimators (Chao 2) indicated that $75 \%$ of the species present were sampled. Species richness and diversity was greatest in tropical forests. Species geographic distributions were found to fall into 3 categories: mega-Mexico, tropical and temperate. The majority of the species $(55.3 \%)$ were restricted to mega-Mexico (southern southwestern US to northern Nicaragua), with fewer species with tropical (27.7\%) and temperate (17.0\%) distributions. Species with tropical distributions had highest diversity and greater overall abundance in low elevations in tropical forests when compared to higher elevation forests (cloud and pine/oak). In contrast, diversity and abundance for species with temperate and mega-Mexican distributions were similar in all forest types. Greater richness and abundance occurred during the dry season (December through May) than the rainy season, suggesting populations of Apionidae were in immature stages during this latter period, with active adults predominating during the dry season, many of which were probably in a non-reproductive physiological state.
\end{abstract}

Key words: Coleoptera, biodiversity, biosphere reserve, Apionidae, neotropical.

Resumen. Se estudiaron las distribuciones altitudinales y temporales de especies de la familia Apionidae (Coleoptera: Curculionoidea) en la Reserva de la Biosfera El Cielo, en el norte de México. Riqueza, diversidad y abundancia fueron registrados a través de un gradiente altitudinal de 100 hasta $1900 \mathrm{~m}$. Se recolectó un total de 571 individuos de Apionidae de 51 especies. La diversidad de especies fue mayor en la selva tropical. La distribución geográfica de las especies corresponde a 3 categorías: mega-México, tropical y templada. La mayoría de las especies (55.3\%) pertenecen a la categoría mega-México (sur del suroeste de los Estados Unidos hasta el norte de Nicaragua), seguido por especies con distribución tropical (27.7\%) y templada (17.0\%). Las especies con distribución tropical tuvieron mayor diversidad y abundancia en elevaciones bajas (selvas tropicales). En contraste, la diversidad y abundancia de las especies con distribución templada y mega-México fueron parecidas entre altitudes y tipos de vegetación. Se encontró mayor riqueza y abundancia durante la época de secas (diciembre a mayo) que en la época de lluvias, lo cual sugiere que las poblaciones de Apionidae estuvieron en etapa de inmaduros durante este último periodo, con una predominancia de adultos activos durante la época de secas, los cuales probablemente estuvieron en un estado fisiológico no-reproductivo.

Palabras claves: Coleoptera, biodiversidad, reserva biosfera, Apionidae, neotropical.

\section{Introduction}

Mexico has long been recognized as a "transition zone" between the Nearctic and Neotropical biogeographic realms (Wallace, 1876; Morrone, 2005). In generalized

Recibido: 25 febrero 2011; aceptado: 04 agosto 2011 biogeographic maps (Wallace, 1876; Udvardy, 1975; Olson et al., 2001; Cox and Moore, 2005), the Neotropical region of Mexico is generally shown to occur south of the Isthmus of Tehuantepec and extend north along both western and eastern coastal areas approximately to the Tropic of Cancer. In contrast, the Nearctic region extends from the Rocky Mountains south through the central Mexico plateau and along the 2 northern mountains ranges 
(Sierra Madre Oriental and Occidental), terminating at the Transverse Neovolcanic Belt at approximately $18^{\circ}$ latitude north. Although this generalized Nearctic-Neotropical pattern is useful for a rough depiction of the distribution within Mexico of species from these biogeographic regions, the actual distribution patterns of individual species and genera are complex and the result of dispersal and/or vicariant speciation processes associated with a wide range of possible geographical or environmental changes in geological time (Halfter, 1987; Noonan, 1988; Thomas, 1993; Rzedowski, 1993; Lobo and Halffter, 2000; Marshall and Lieberr, 2000; Morrone and Márquez, 2008).

The northern extension of the Sierra Madre Oriental Biotic province (sensu Morrone et al., 2001), and in particular the region protected within the El Cielo Biosphere Reserve (ECBR), is one of the geographic areas of Mexico where the contrast and mixing between the nearctic and neotropical faunal and floral elements is most pronounced. This reserve is in the state of Tamaulipas, approximately $70 \mathrm{~km}$ south of Ciudad Victoria between $22^{\circ} 55^{\prime}$ and $23^{\circ} 25^{\prime}$ $\mathrm{N}$ and $99^{\circ} 05^{\prime}$ and $99^{\circ} 26^{\prime} \mathrm{W}$ (Casas Gonzalez and Requena Lara, 2005). González-Medrano (2005) reports 10 distinct types of vegetation in ECBR including tropical deciduous forests, tropical semi-deciduous forest, cloud forest, pine forest, oak forest, pine-oak forest, and with 4 associations of xeric shrubs on the western portions of the reserve. These vegetation types are often found in close proximity and several associations can often be found within a distance of $10 \mathrm{~km}$, especially where the terrain rises abruptly (Valiente-Banuet et al., 1995; Gonzalez-Medrano, 2005). These changes in vegetation provide an opportunity to examine how different floral and faunal groups are distributed and mix within the different habitats.

Our overall objective was to identify the species in the family Apionidae (Coleoptera: Curculionoidea, sensu Alonso-Zarazaga and Lyal, 1999) and to characterize their distributions and associations in ECBR. Apionidae is a family of relatively small weevils $(<7 \mathrm{~mm})$ with non-geniculate antenna, elongated trochanter and usually pear-like shape (Anderson and Kissinger, 2002). Apionidae are widely distributed with approximately 1900 described species worldwide (Oberprieler et al., 2007) and reported from all the biogeographical regions of the world, except the Antarctica (Alonso-Zarazaga, 2004). They are phytophagous and relatively host plant specific (Alonso-Zarazaga, 2004) and immature stages develop in plant inflorescences, seeds, stems or roots (Anderson and Kissinger, 2002; Alonso-Zarazaga, 2004). The family Apionidae was selected for the following reasons: 1), identification to species was possible for most species; 2), distribution records were available for all identified species (Kissinger, 1968, 1989, 1992, 1998, 1999a, 1999b;
O'Brien and Wibmer, 1982); 3), although studies have examined the diversity of various tropical insect groups along altitudinal gradients (Sánchez-Ramos et al., 1993; Olson, 1994; Lobo and Halffter, 2000; Sandoval and Fagua, 2006), none have presented detailed, site specific diversity data for a phytophagous taxa such as Apionidae.

We determined the richness, abundance and diversity of Apionidae along an altitudinal gradient that included semi-deciduous tropical forest $(100-700 \mathrm{~m})$, cloud forest (800-1 $400 \mathrm{~m}$ ) and mixed pine-oak forests (1 500-1 900 $\mathrm{m})$, with the limits of vegetation types based on GonzalezMedrano (2005). Using reported distribution data, we categorized distributions of species of Apionidae into 3 categories and compared species richness and abundance of the different biogeographic categories along the altitudinal gradient and temporally throughout a year of collection.

The principal questions addressed were the following: 1 ), what is the richness and diversity of Apionidae en the El Cielo Biosphere Reserve? 2), what are the basic biogeographic affinities the species of Apionidae within the reserve? 3), are the species of Apionidae of different biogeographic affinities restricted to different altitudes? and, 4), what are the seasonal patterns in abundances and altitudinal distributions of Apionidae within the vegetation types of the reserve?

\section{Materials and methods}

An altitudinal transect was established approximately 8 $\mathrm{km}$ north of the town of Gómez Farías, in the municipality of Gómez Farías, Tamaulipas, México, and oriented in a east to west direction from $23^{\circ} 07^{\prime} 56^{\prime \prime} \mathrm{N}, 99^{\circ} 08^{\prime} 50^{\prime \prime} \mathrm{W}$ to $23^{\circ} 07^{\prime} 56^{\prime \prime} \mathrm{N}, 99^{\circ} 08^{\prime} 50^{\prime \prime} \mathrm{W}$. RBEC is situated in the terrestrial subregion of the Sierra Madre Oriental (Cuanalo de la Cerda et al., 1989), and situated in the Sierra de las Cucharas, part of the ancient Sierra de Guatemala (Cámara Artigas and González Rodriguez, 2005). The region is composed of tropical karst of medium tropical hills and mountains reaching a maximum of $2320 \mathrm{~m}$ a.s.l., with karstic depressions in the valleys (Cámara-Artigas and González-Rodriguez, 2005). Soils are primarily litisols for the length of the transect. Using the system of classification of Garcia (1973), the climate of the lower sections of the transect up to $700 \mathrm{~m}$ is classified as (A) $\mathrm{C}\left(\mathrm{w}_{2}\right)$ and $\mathrm{C}\left(\mathrm{w}_{2}\right)$ from 700 to $1900 \mathrm{~m}$ (Casa-Gonzalez and Requena-Lara, 2005). Vegetation of the transect included deciduous and semi-deciduous tropical forest (selva mediana caducifolia y subcaducifolia) at 100-700 m; cloud forest (bosque mesófilo de montaña) from 700 to $1400 \mathrm{~m}$; and oak-pine forest (bosque de encino-pino) from 1400 to 1900 m (Cámara-Artigas and González-Rodriguez, 2005; González-Medrano, 2005). 
Samples were taken monthly at 19 sites, each at 100 $\mathrm{m}$ intervals $(19 \times 12$ months $=228$ samples total $)$, along an altitudinal transect from $100 \mathrm{~m}$ to $1900 \mathrm{~m}$ a.s.l. within ECBR from January to December of 1998. Samples were taken at successive sites along the transect corresponding to $100 \mathrm{~m}$ of altitude from 100 a $1900 \mathrm{~m}$; the distance between sample sites depending on the steepness of the terrain. Of these sites, 7 sample sites were located in tropical deciduous forest, 7 with cloud forest and 5 within oak/ pine forests. The classification and altitudinal extension of vegetation at sample locations were based on GonzalezMedrano (2005) and Puig (2005), with 7 sites categorized as tropical deciduous forest (100-700 m), 7 as cloud forest (800-1 $400 \mathrm{~m}$ ) and $5 \mathrm{as}$ oak/pine forest (1 500-1 $900 \mathrm{~m})$. We found no standardized sampling procedure for Apionidae and considered standard sweep net samples appropriate given the small size of these weevils and their close association with plants (Alonso-Zarazaga, 2004). Samples at each site consisted of 200 sweeps of vegetation using a standard $38 \mathrm{~cm}$ diameter canvas sweep net. At each sample location, efforts were made to sweep all vegetation that was accessible within the area. All material from the 200 sweeps, including plant parts and assorted debris, was placed in 1 gallon Zip-Lock ${ }^{\circledR}$ plastic bags saturated with alcohol, labeled with date and collecting site, and brought to the laboratory. Adult weevils were separated from the samples by visual inspection using a $1.75 \mathrm{x}$ magnifying lamp, and then mounted and labeled. Individuals were sorted to morphospecies and then identified using the descriptions and keys in Kissinger (1968, 1989, 1992, 1998, 1999a, 1999b), or identified by David G. Kissinger of Loma Linda, California, as well as by comparison with identified material. All specimens were deposited in the entomological collection of the Universidad Autónoma de Querétaro, Querétaro, México (UAQE), or that of David G. Kissinger, Loma Linda, CA (DGK).

Species distributional analysis. The geographic distributions of species of Apionidae were divided into 3 categories: 1) mega-Mexico, 2) tropical, and 3) temperate. The category mega-Mexico corresponded to "megaMexico 3" of Rzedowski (1993); a distribution that includes the extreme southwestern United States, Mexico and northern Central America (to northern Nicaragua). Tropical species were those that occur within mega-Mexico 3 , sometimes found as far north as the southwestern United States, but extend south beyond northern Central America into southern Central America and, rarely, into South America. The species categorized as temperate species had distributions extending north of the southwestern United States (north of the limits of mega-Mexico 3), with distributions extending south into Mexico and, rarely, into northern Central America.
Diversity measures and statistical analysis. The number of individuals per species was recorded for each sample and sample site. These data were used to estimate total weevil richness and diversity, as well as for separate estimates for tropical deciduous forest, cloud forest, and oak/pine vegetation types. The categories of vegetation were based on the classifications and geographic locations given by González-Medrano (2005). Species accumulation curves and estimators of diversity were calculated using EstimateS 6.0 computer program (Colwell, 1997). The species richness estimators Chao 2 and first order jackknife (Jack 1) (Colwell and Coddington, 1994) were chosen for use because Chao 2 has shown good performance with arthropod data, and Jackknife 1 is generally considered a conservative estimator (Magurran, 2004). These estimators were calculated for the entire transect and for each vegetation type. Diversity indices, Shannon $\left(\mathrm{e}^{\mathrm{H}^{\prime}}\right)$ and Simpson's (inverse) were also calculated using EstimateS 6.0 for all samples and for each of the vegetation types and tested for significant differences between habitats using methods given by Magurran (2004). After testing for normal distributions, differences in abundance of individuals (all combined species for biogeographic categories, monthly and seasonal (totals) were investigated using KruskallWallis and Mann-Whitney nonparametric procedures using the statistical software MiniTab ${ }^{\circledR}$, Release 14.

\section{Results}

Species richness and diversity. A total of 571 individuals representing 51 species within 9 genera of Apionidae were collected (Table 1 and Appendix). The total species richness estimate suggested that approximately $75 \%$ of the total number of species of Apionidae were sampled (75.1\% and $74.0 \%$ for estimators Chao 2 and first order Jacknife, Table 1). Within the genera observed, Trichapion had 19 species, Coelocephalapion 14, Kissingeria 6, Apionion 3, Chrysapion, Alocentron, Neapion, and Sayapion each 2, and Stenapion had 1 species. The most abundant species were Coelocephalapion decoloratum (Smith) with 81 individuals, Alocentron relictum (Sharp) with 60, and Kissingeria trichium (Kissinger) with 51.

Species richness and diversity of Apionidae varied among forest types. Species richness was highest in the tropical semi-deciduous forest followed by cloud forest and oak-pine forest (Table 1). Richness estimates (Chao 2 and Jackknife1) also indicated that the tropical deciduous forest had the greatest richness followed by cloud forest and oak/pine forest although these differences were not significant (Table 1). Diversity measures and total abundances were significantly different among vegetation types (Table 1). Species diversity of Apionidae, measured 
Table 1. Estimated richness and diversity indices of species of Apionidae (Insecta: Coleoptera) calculated from different vegetation types in the El Cielo Biosphere Reserve, Tamaulipas, Mexico

\begin{tabular}{|c|c|c|c|c|c|c|}
\hline \multirow[b]{2}{*}{ Vegetation type } & \multicolumn{3}{|c|}{ Richness estimators $^{I}$} & \multirow[b]{2}{*}{ Jacknife 1} & \multicolumn{2}{|c|}{ Diversity index ${ }^{2}$} \\
\hline & Observed & $\begin{array}{c}\text { Confidence interval, 95\% } \\
\text { (Mao Tao) }\end{array}$ & Chao 2 & & $\begin{array}{c}\text { Shannon } \\
\left.\text { (Exponential: } e^{H^{\prime}}\right)\end{array}$ & $\begin{array}{l}\text { Simpson } \\
\text { (inverse) }\end{array}$ \\
\hline Tropical Semi- & & & & & & \\
\hline Deciduous Forest & 31 & $22.91-39.09$ & $44.04+8.79 \mathrm{a}$ & $42.86+4.01 \mathrm{a}$ & $17.5 \mathrm{a}$ & $12.88 \mathrm{a}$ \\
\hline Cloud Forest & 28 & $20.37-35.63$ & $35.76+5.71 \mathrm{a}$ & $38.87+3.92 \mathrm{a}$ & $11.7 \mathrm{~b}$ & $9.50 \mathrm{~b}$ \\
\hline Oak-Pine Forest & 19 & $14.36-23.64$ & $24.90+4.89 \mathrm{a}$ & $27.85+2.74 \mathrm{a}$ & $7.5 \mathrm{c}$ & $5.24 \mathrm{c}$ \\
\hline Total & 51 & $43.55-58.55$ & $67.93+9.27$ & $68.92+4.30$ & 24.8 & 17.29 \\
\hline
\end{tabular}

1 / Estimators within columns for vegetation types with the same letter not significantly different $(p>0.05)$ based on $\log \operatorname{linear}$ confidence intervals calculated using EstimateS 6.0 software (Colwell 1997).

2/ All comparisons of diversity indices between vegetation types significantly different $(p<0.05)$; for all comparisons values of Students $\mathrm{t}>55.0, \mathrm{df}>350$.

by both Shannon $\left(\mathrm{e}^{\mathrm{H}}\right)$ and Simpson (inverse) Indices, was greatest in the semi-deciduous tropical vegetation, followed in order by cloud forest and oak/pine forest vegetation (Table 1). Higher diversity in tropical vegetation was the result of both greater numbers of species and more uniform abundance patterns. In contrast, the uniformity of species abundance in oak/pine was low, reducing diversity measures, with 5 dominant species (C. auctum, C. decoloratum, K. trichium, T. godmani, T. proclive) accounting for $81 \%$ of the recorded individuals. In contrast to diversity values, overall abundance was not significantly different among forest types $(\mathrm{H}=1.6, \mathrm{df}=2, p>0.05)$. Biogeographic affinities. The distribution of species of Apionidae from ECBR fit well into the 3 biogeographic patterns (Fig. 1). The geographic distribution of the majority of the Apionidae species (56.5\%; $26 \mathrm{spp}$.) in the reserve corresponded to mega-Mexico 3 of Rzedowski (1993). Of these species, $15(57.7 \%)$ had distributions restricted to regions north of the Isthmus of Tehuantepec and $3(6.5 \%)$ have only been collected from the Sierra Madre Oriental. Tropical species, those with distributions whose northern limits are within mega-Mexico 3 but extend south beyond northern Central America, accounted for $28.3 \%$ (13) of the species. Of these, only 3 had distributions beyond Panama into South America. The species categorized as temperate species, with distributions extending north of the limits of mega-Mexico into the United States or rarely into Canada, accounted for only $15.2 \%$ of the total. Of these, none have been found in South America, southern Central America or the Caribbean and only 2 had distributions that extended beyond the Isthmus of Tehuantepec.

Species from the 3 biogeographic categories were found in all vegetation types (Fig. 2), and the proportions of the categories among the habitat types were not significantly different $\left(\chi^{2}=3.26, \mathrm{df}=2, p>0.05\right)$. However, of these categories, those with tropical distribution had greatest differences in species richness and abundance among vegetation types (Fig. 2A, B). Greater species richness and significantly higher abundance of tropical species were found in tropical and cloud forests than in the oak/pine forests at higher elevations (Fig. 2B). Species richness for Apionidae with distributions within mega-Mexico was similar for all vegetation types (Fig. 2B). Species with temperate distributions had similar richness values for all

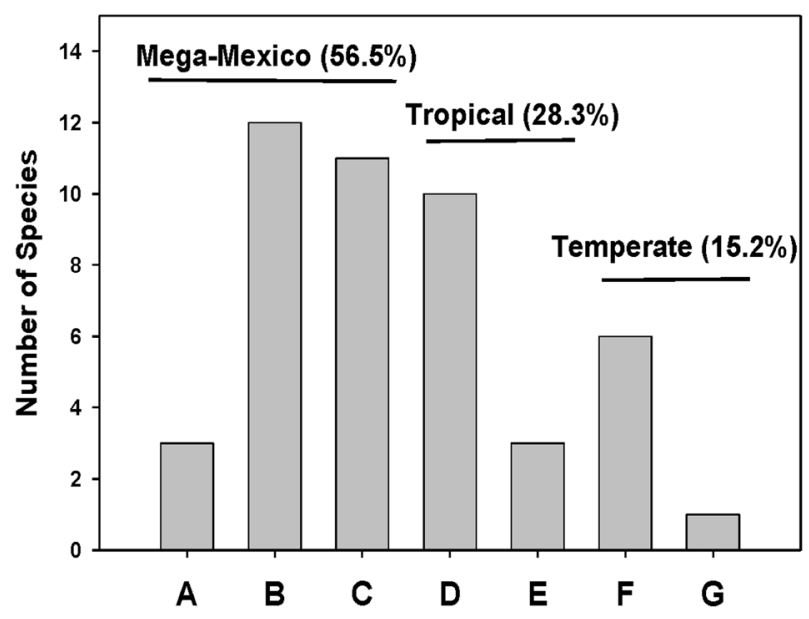

Figure 1. Geographic distributions of species of Apionidae in the El Cielo Bisophere reserve. See text for definition of the 3 geographic categories (mega-Mexico, tropical, and temperate). Distributions within these categories included: A, only recorded from the Sierra Madre Oriental; B, reported from northern megaMexico and not extending beyond the Isthmus of Tehuantepec; C, distributed throughout mega-Mexico (southwestern US to northern Central America); D, mega-Mexico to southern Central America; E, mega-Mexico to South America; F, USA and/or Canada to northern Mexico; G, USA and sometimes Canada to northern Central America. 
vegetation types, with slightly greater abundance in oakpine forests (Fig. 2B).

Seasonal abundance patterns. Species richness and abundance of Apionidae were greater during the dry season (December through May) than the rainy season (June through November). A total of 40 species were registered during the dry season compared with 28 collected from the rainy season. Likewise, overall abundance (individuals per sample) was significantly greater during dry season months than the wet season $(\mathrm{H}=7.4, p<0.05)$, as well as for each abundance within each biogeographic category; $\mathrm{U}=5012,6079$, and 4957, $(p<0.05)$ respectively for tropical, temperate, and mega-Mexico affinities. However, despite differences in abundance, the proportions of species within the 3 biogeographic categories was not significantly different between seasons $\left(\chi^{2}=0.61, \mathrm{df}=4, p>0.05\right)$.

Monthly richness and abundance values for Apionidae were notable for marked decreases at the start of the rainy season in June and July (Fig. 3). Subsequently, richness generally increased throughout the rainy season and into the dry season, peaking during February, March and April. In contrast, abundance values were bimodal. The first peak occurred from February to May with the second peak from September through December. All abundance values for these months, with the exception of October, were significantly greater than the lowest abundance values at the beginning of the rainy season in June and July (Fig. 3).

\section{Discussion}

The number of species of Apionidae (51) collected within ECBR was notable for such a small sample area and represented $30 \%$ of the total number of species reported for Mexico by Alonzo-Zarazaga (2004). This richness is due, in part, to the reserve having both tropical and temperate climate regimes, as well as being located at a node of 3 biogeographic provinces (Morrone and Márquez, 2008): Sierra Madre Oriental, Gulf Coast and Tamaulipan. Richness estimators (Chao 2 and Jacknife 1) indicated that approximately $75 \%$ of the species of Apionidae were collected in the habitats sampled. Further collection effort within the western portions of the reserve with vegetation characteristic of the more arid Tamaulipan biotic province will undoubtedly contribute more species of Apionidae representative of northern Mexico.

Diversity was greater in the tropical deciduous forest, than in cloud or pine/oak forests, due to greater numbers of species combined with more uniform abundances in the former, although abundance was similar among forests. Because Apionidae are relatively host specific (AlonsoZarazaga, 2004) these results are probably a product of the greater diversity of hosts plants in the tropical forest; an explanation that is supported by general comparisons of diversities of insect herbivores between temperate and tropical forests (Novotny et al., 2006).

The biogeographic distributions of the majority of the species of Apionidae from ECBR were restricted to megaMexico 3, or from this region south into southern Central America ( $85 \%$ of total). Thus, although the reserve is only $350 \mathrm{~km}$ from the US border, the biogeographic affinities of the species of Apionidae are distinctly to the south. This pattern is in contrast to other taxa of ECBR, such as trees (Puig, 2005) and macrofungi (García-Jiménez and Valenzuela-Garza, 2005) of the cloud forests of ECBR that share many species with temperate regions of the southeastern United States. Only 7 of the species of Apionidae collected have distributions that extended north beyond the extreme southwestern United States (Fig. 1), and of these, only 3 have been reported from the eastern US. The low number of shared species between ECBR and the eastern United States may be the result of more rapid divergence and vicariant speciation of populations of Apionidae between these regions when compared to other taxa; this given that these insects often have multiple generations per year and can reach high local abundance.

Although the region of mega-Mexico 3 was originally conceived to describe distributions of plants (Rzedowski, 1993), the concept also characterizes well the majority of the distribution patterns of species of Apionidae from ECBR. Surprisingly, it also delimits the majority of all species of Apionidae recorded for North America (52\%, $\mathrm{n}=246$; Kissinger, 1968); a figure similar to that reported here for the ECBR. It can be argued that the similarity in distribution between Apionidae and Mexican plants is because the insects simply track their host plants, but as so little is known of the host plants of Apionidae, this conclusion presently cannot be properly evaluated. Nonetheless, it is interesting to note that the one megaMexican species from this study with reliable host plant data (Neapion xanthoxyli), has a host plant with a much greater geographic distribution. Its host plant, Zanthoxylum fagara (L.) Sarg. is fairly common in Florida and in the Caribbean (Correll and Johnston, 1970), That the distribution of $N$. xanthoxyli is more restricted than that of its host plant is not surprising given that herbivores generally cannot colonize all plant populations, as has been noted by Gaston (2003). Further study is needed to determine if other species of Apionidae restricted to megaMexico do not extend to the full northern range of their host plants.

More species and individuals of Apionidae were found during the dry season than the rainy season which apparently reflects the basic life history of Apionidae in 

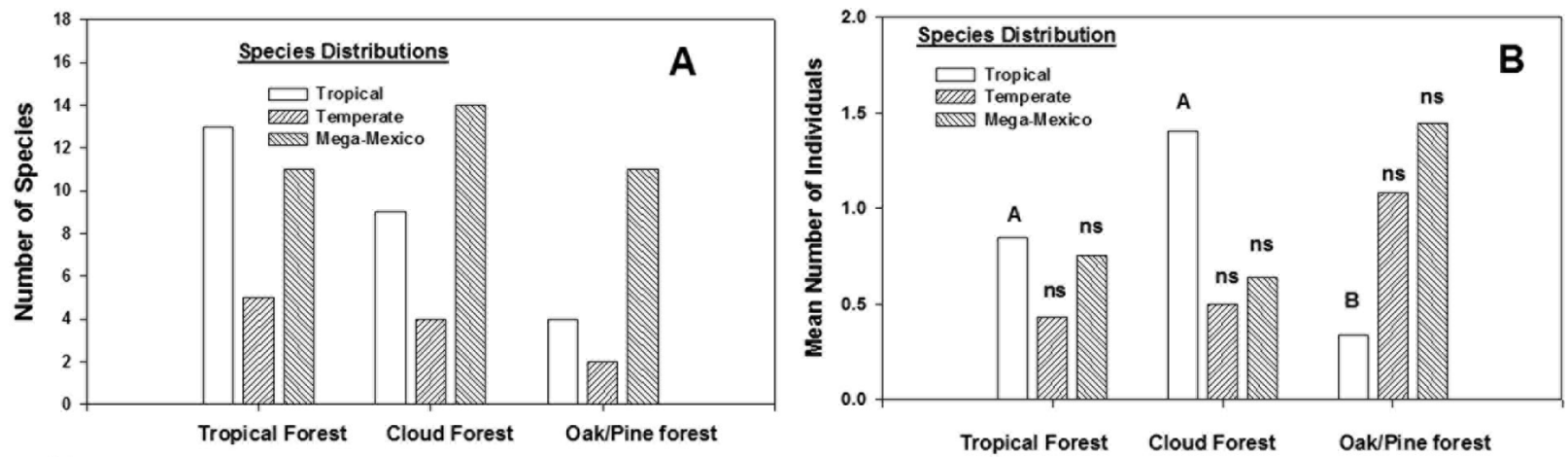

Figure 2. Comparison of species richness and total individual densities of Apionidae (Coleoptera) among vegetation types in the El Cielo Biosphere Reserve. A, numbers of species of each geographic distribution category compared among vegetation types. B, mean abundance of total individuals per sample of each geographic distribution category compared among vegetation types. Mean number of individuals of tropical distribution were significantly higher in tropical forest and cloud forests than oak/pine forests (Kruskall Wallis, $\mathrm{H}=10.59 ; \mathrm{DF}=3 ; p<0.01$, separation of ranks between each forest type using Mann-Whitney Test).

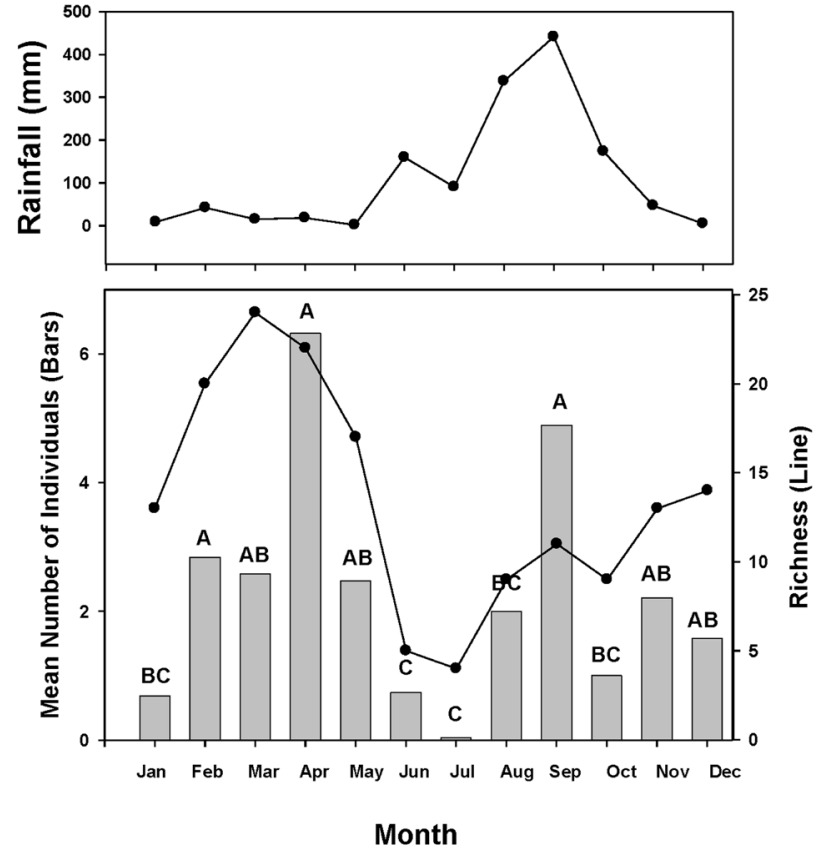

Figure 3. Monthly totals of rainfall (top) with species richness and mean abundance of Apionidae (bottom) in the El Cielo Biosphere Reserve, Tamaulipas, Mexico. Bars with same letters not significantly different based on Kruskall-Wallis nonparametric test $(\mathrm{H}=26.7 ; \mathrm{DF}=3 ; p<0.01$, separation of ranks between months using Mann-Whitney Test).

the reserve. As strictly herbivorous insects, Apionidae are limited to reproduction on a limited number of plant species with immature stages of Apionidae virtually immobile and restricted within reproductive and vegetative structures. Clearly adult females are obligated to be closely associated with the hosts at times of oviposition, but adults may be on other plant species that are not larval hosts during mating flights or resting stages especially when hosts are unavailable (Alonso-Zarazaga, 2004). These host-free periods may be extensive, at times lasting more than 6 months, depending on climate and plant phenology. In the reserve, a significant drop in adult abundance during June and July at the initiation of the rainy season, suggested that populations were principally on primary hosts in immature stages at this time. As these stages developed into adults, these apparently began appearing in all habitats and reached peak richness and abundance in March and April. Individuals collected during these peak periods of abundance, were probably on non-reproductive hosts, as is commonly reported for Apionidae (Alonso-Zarazaga, 2004). This conclusion is supported by the presence of many individuals with distributions categorized as tropical or mega-Mexico in the higher elevation oak/pine forests at these peak abundance periods. This further suggests that at least some of the species of Apionidae may seasonally disperse during periods of adult aestivation from lower to cooler, higher elevations when host plants are not available and temperatures at the lower altitudes are extreme.

Clearly, more study is needed of the basic biology of species of Apionidae and their host plants in subtropical and tropical regions. In the present study, only 7 of the species have published reliable host records, of which 5 are for temperate species of Apionidae based on data recorded in the United States and Canada. More detailed host plant records would allow for interesting comparisons of the local and biogeographic distributions species of species of Apionidae with that of their host plants and give insight into life history traits and distribution and colonization patterns at various spatial scales. 


\section{Acknowledgments}

We are indebted to David Kissinger of Loma Linda, California for identification of many of the collected specimens. We wish to thank Plácido Ornelas Linares, Julián Maldonado Contreras, Jesús Hernández Martínez, Humberto Osorio, Joaquín Parra Niño, Juan Córdoba y Teresa de Jesus Ornelas Linares who helped in the field work and Texas Southmost College, in Brownsville, Texas and their personnel at El Cielo Biological Station for providing housing and research space. Mahinda Martínez, Carlos López and Karina Acevedo-Whitehouse of the Universidad Autónoma de Querétaro provided valuable editorial advice. Funding was provided in part by the Comisión para el Conocimiento y Uso de la Biodiversidad (CONABIO) and the Universidad Autónoma de Querétaro.

\section{Literature cited}

Alonso-Zarazaga, M. A. 2004. Apionidae (Coleoptera). In Biodiversidad, taxonomía y biogeografía de artrópodos de México: hacia una síntesis de su conocimiento. Vol. IV, J. Llorente Bousquets, J. J. J. Morrone, O. Yañez and I. Vargas (eds.). Facultad de Ciencias, Universidad Nacional Autónoma de México y Comisión Nacional para el Conocimiento y Uso de la Biodiversidad, Mexico, D. F. p. 705-712.

Alonso-Zarazaga, M. A. and C. H. C. Lyal. 1999. A World Catalogue of Families and Genera of Curculionoidea (Insecta: Coleoptera), (Excepting Scolytidae and Platypodidiae). Entomopraxis, Barcelona. 315 p.

Anderson, R. and D. G. Kissinger. 2002. Chapter 129. Brentidae. Billberg 1820. In American Beetles: Polyphaga: Scarabaeoidea through Curculionoidea, R. H. Arnett and M. C. Thomas, (eds.). CRC Press, New Cork. p. 711-719.

Casas-González, S. L. and G. N. Requena-Lara. 2005. Chapter 3. Generalidades geográficas. In Historia Natural de la Reserva de la Biosfera El Cielo, Tamaulipas, México, G. SánchezRamos, P. Reyes-Castillo and R. Dirzo (eds.). México, Universidad Autónoma de Tamaulipas. p. 38-50.

Cámara-Artigas, R. and L. González-Rodriguez. 2005. 5. Un karst tropical en la Sierra Madre Oriental. In Historia Natural de la Reserva de la Biosfera El Cielo, Tamaulipas, México, G. Sánchez-Ramos, P. Reyes-Castillo and R. Dirzo (eds.). México, Universidad Autónoma de Tamaulipas. p. 63-66.

Colwell, R. K. and J. A. Coddington. 1994. Estimating terrestrial biodiversity through extrapolation. Philosophical Transactions of the Royal Society 345:101-118.

Colwell, R. K. 1997. EstimateS: Statistical estimation of species richness and shared species from samples. Version 5. User's guide and application: http:// viceroy.eeb.uconn. edu/ estimates; 28.VII.2011.

Correll, D. S. and M. C. Johnston. 1979. Manual of the Vascular
Plants of Texas. University of Texas, Austin, TX. 1881 p.

Cox, B. C. and P. D. Moore. 2005. Biogeography: An ecological and evolutionary approach. $7^{\text {th }}$ ed., Blackwell Scientific, Oxford. 326 p.

Cuanalo-de la Cerda, H., E. Ojeda-Trejo, A. Santos-Ocampo and C. A. Ortiz-Solorio. 1989. Provincias, Regiones y Subregiones de México. Colegio de Postgraduados, Centro de Edafología, Chapingo, México. 621 p.

García, E. 1973. Modificaciones al sistema de clasificación climática de Köppen (para adaptarlo a las condiciones de la República Mexicana). 2. ed. Instituto de Geografía, Universidad Nacional Autónoma de México, México D.F. $220 \mathrm{p}$.

García-Jiménez, J. and R. Valenzuela-Garza. 2005. Chapter 30. Hongos macromicetos. In Historia Natural de la Reserva de la Biosfera El Cielo, Tamaulipas, México, G. Sánchez-Ramos, P. Reyes-Castillo and R. Dirzo (eds.). México, Universidad Autónoma de Tamaulipas. p. 321-337.

Gaston, K. J. 2003. The structure and dynamics of geographic ranges. Oxford University Press, Oxford. 266 p.

Gonzalez-Medrano, F. 2005. Chapter 7. La vegetación. In Historia Natural de la Reserva de la Biosfera El Cielo, Tamaulipas, México, G. Sánchez-Ramos, P. Reyes-Castillo, and R. Dirzo (eds.). Universidad Autónoma de Tamaulipas. Universidad Autónoma de Tamaulipas. México. p. 88-105.

Green, R. H. 1966. Measurement of non-randomness in spatial distributions. Researches Population Ecology 8:1-7.

Halffter, G. 1987. Biogeography of the Montane Entomofauna of Mexico and Central America. Annual Review of Entomology 32:95-114.

Hammer, Ø., D. A. T. Harper and P. D. Ryan. 2001. PAST: Paleontological Statistics Software Package for Education and Data Analysis. Palaeontologia Electronica 4:9.

Kissinger, D. G. 1968. Curculionidae subfamily Apioninae of North and Central America, with reviews of the World genera of Apioninae and World subgenera of Apion Herbst Coleoptara. Taxonomic Publications, South Lancaster. 559 p.

Kissinger, D. G. 1989. Apionidae from North and Central America. Part 1. Notes on the classification of the Apion subgenus Trichapion Wagner with description of new species from the United States of America. (Coleoptera). Insecta Mundi 3:271-287.

Kissinger, D. G. 1992. Apionidae from North and Central America. Part 4. Generic classification and introduction to the genus Coelocephalapion Wagner, with new species from Mexico and Venezuela (Coleoptera). Insecta Mundi 6:65-77.

Kissinger, D. G. 1998. Apionidae from North and Central America. Part 5. Description of genus Apionion and 4 new species (Coleoptera). Insecta Mundi 12:93-102.

Kissinger, D. G. 1999a. Description of a new genus, Sayapion, from from North and Central America. (Coleoptera: Apionidae). Insecta Mundi 13:72. 
Kissinger, D. G. 1999b. Apionidae from North and Central America. Part 6. Description of new species of Apionion Kissinger, Coelocephalapion Wagner and Trichapion Wagner (Coleoptera). Insecta Mundi 13:21-37.

Lobo, J. M. and G. Halffter. 2000. Biogeographical and ecological factors affecting the altitudinal variation of mountainous communities of coprophagous beetles (Coleoptera: Scarabaeoidea): A comparative study. Annals Entomological Society of America 93:115-126.

Magurran, A. E. 2004. Measuring biological diversity. Blackwell Pub. New York. 256 p.

Marshall, C. J. and J. K. Lieberr. 2000. Cladistic biogeography of the Mexican transition zone. Journal of Biogeography 27:203-216

Morrone, J. J. 2005. Hacia una síntesis biogeográfica de México. Revista Mexicana de Biodiversidad 76:207-252.

Morrone, J. J., D. Espinosa and J. Llorente. 2002. Mexican biogeographic provinces: Preliminary scheme, general characterizations, and synonymies. Acta Zoológica Mexicana 85:83-108.

Morrone, J. J. and J. Márquez. 2008. Biodiversity of Mexican terrestrial arthropods (Arachnida and Hexapoda): a biogeographical puzzle. Acta Zoológica Mexicana 24:15-41.

Noonan, G. R. 1988. Biogeography of North American and Mexican insects, and a critique of vicariance biogeography. Systematic Zoology 37:366-384.

Novotný, V. and Y. Basset. 2000. Rare species in communities of tropical insect herbivores: pondering the mystery of singletons. Oikos 89:564-572.

Novotny, V., P. Drozd, S. Miller, M. Kulfan, M. Janda, Y. Basset and G. D. Weiblen. 2006 Why are there so many species of herbivorous insects in tropical rain forests? Science 313:1115-1118.

Oberprieler, R. G., A. E. Marvaldi and R. S. Anderson. 2007. Weevils, weevils, everywhere. Zootaxa 1668:491-520.

O'Brien, C. W. and G. J. Wibmer. 1982. Annotated checklist of the weevils (Curculionidae sensu lato) of North America, Central America and the West Indies (Coleoptera : Curculionidae).
Memoirs American Entomological Institute. 34:1-382.

Olson, D. M., E. Dinerstein, E. D. Wikramanayake, N. D. Burgess, G. V. N. Powell, E. C. Underwood, J. A. D'amico, I. Itoua, H. E. Strand, J. C. Morrison, C. J. Loucks, T. F. Allnutt, T. H. Ricketts, Y. Kura, J. F. Lamoreux, W. W. Wettengel, P. Hedao and K. R. Kassem. 2001. Terrestrial Ecoregions of the World: A New Map of Life on Earth. BioScience 51:933-938.

Olson, D. M. 1994. The distribution of leaf litter invertebrates along a Neotropical altitudinal gradient. Journal of Tropical Ecology 10:129-150.

Puig, H. 2005. La biogeografía de las plantas del bosque mesófilo. In Historia Natural de la Reserva de la Biosfera El Cielo, Tamaulipas, México. Chapter 6, G. Sánchez-Ramos, P. Reyes-Castillo, and R. Dirzo (eds.). Universidad Autónoma de Tamaulipas. México. p. 67-87.

Rzedowski, J. 1993. Diversity and origins of the Phanerogamic flora of Mexico. In Biological diversity of Mexico. Origins and distributions, T. P. Ramamoorthy, R. Bye, A. Lot and J. Fa (eds.). Oxford Univiversity Press, New York. p. 129-146. Sánchez-Ramos, G., J. Lobo. M. Lara-Villalón and P. ReyesCastillo. 1993. Distribución altitudinal y estacional de la entomofauna necrófila en la Reserva de la Biosfera "El Cielo", Tamaulipas, México. Biotam:13-22.

Sandoval-Mojica, A. and G. Fagua. 2006. Estructura de las comunidades de Orthoptera (Insecta) en un gradiente altitudinal de un bosque andino. Revista Colombiana de Entomología 32:200-213.

Thomas, D. B. 1993. Scarabaeidae (Coleoptera) of the Chiapanecan forests: a faunal survey and chorographic analysis. Coleoperist Bulletin 47:363-408.

Udvardy, M. D. F. 1975. A classification of the biogeographical provinces of the world. IUCN Occasional Paper no. 18. Morges, Switzerland: IUCN.

Valiente-Banuet, A., M. F. González and D. Piñero. 1995. La vegetación selvática de la región de Gómez Farías, Tamaulipas, México. Acta Botanica Mexicana 33:1-36.

Wallace, A. R. 1876. The geographical distribution of animals. MacMillian, London. 1110 p.

Appendix. Species list and number of individuals of Apionidae (Coleoptera: Curculionoidea) collected in various forest types in the El Cielo Biosphere Reserve, Tamaulipas, Mexico. Tribal and subtribal arrangements based on Alonso-Zarazaga and Lyal (1999) and species names used as in Alonso-Zarazaga (2004).

$\begin{array}{ccc} & \text { NUMBER OF INDIVIDUALS } & \\ \text { Species } & \text { Sum Trop. Cloud Oak/ } & \text { Geographic } \\ & \text { Forest forest Pine } & \text { distribution }\end{array}$

\section{APIONINAE}

Aspidapiini

Alocentron chiriquense (Sharp)
14

14

$0 \quad 0$

Tropical
USA: (IL); MEXICO (Gro., Mor., Tamps., Ver.); Guat.; Nic. Pan. 
Appendix. Continues.

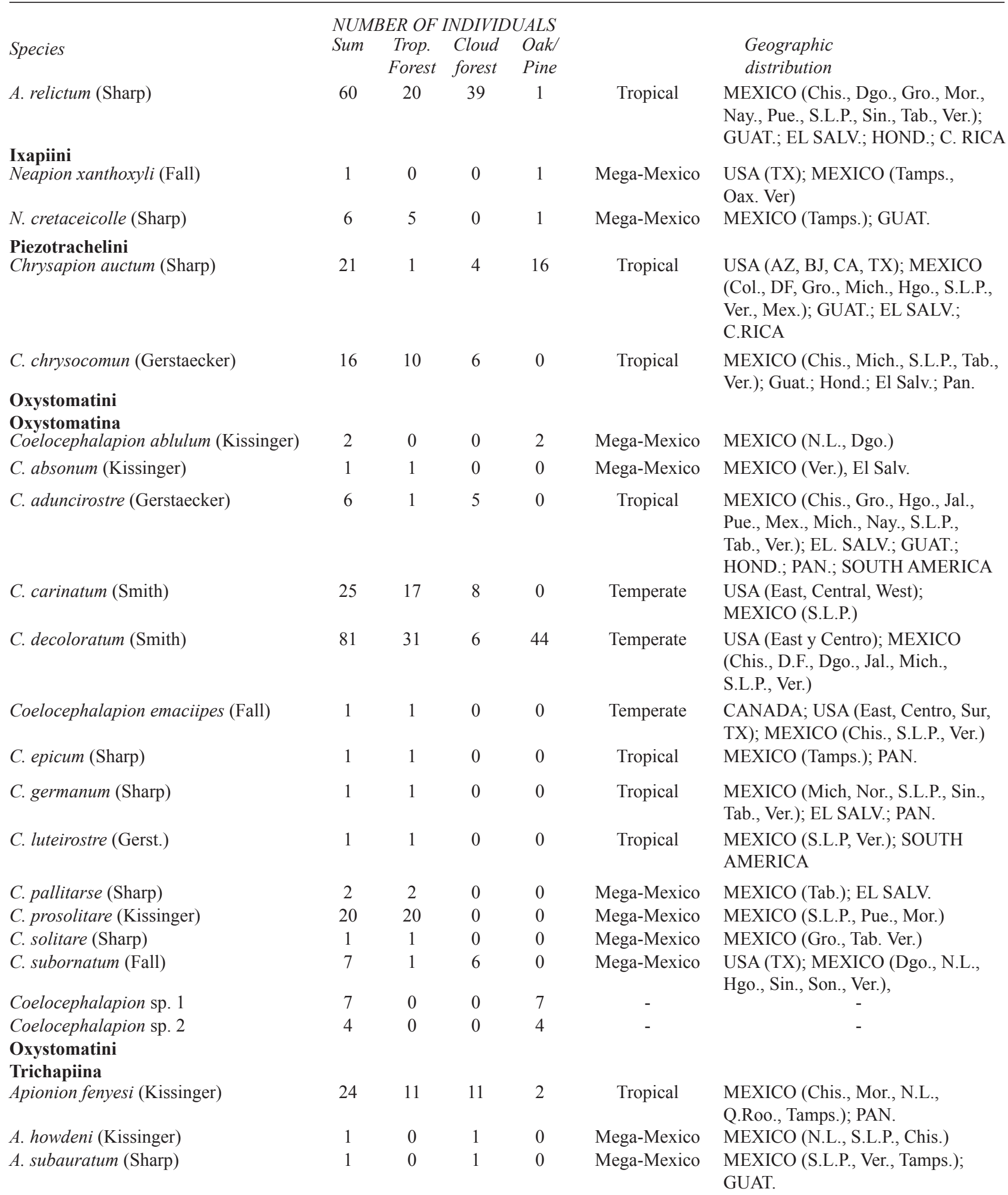


Appendix. Continues.

\begin{tabular}{|c|c|c|c|c|c|c|}
\hline \multirow[b]{2}{*}{ Species } & \multicolumn{4}{|c|}{ NUMBER OF INDIVIDUALS } & \multirow{2}{*}{\multicolumn{2}{|c|}{$\begin{array}{l}\text { Geographic } \\
\text { distribution }\end{array}$}} \\
\hline & Sum & $\begin{array}{l}\text { Trop. } \\
\text { Forest }\end{array}$ & $\begin{array}{l}\text { Cloud } \\
\text { forest }\end{array}$ & $\begin{array}{l}\text { Oak/ } \\
\text { Pine }\end{array}$ & & \\
\hline Kissingeria amaura (Kissinger) & 4 & 0 & 4 & 0 & Temperate & $\begin{array}{l}\text { CANADA; USA (AZ, CA, NM, OK, } \\
\text { TX, ID, OR, UT, WA, AB, CO, IA, } \\
\text { KS, MB, MT, ND); MEXICO (B.C.) }\end{array}$ \\
\hline Kissingeria trichium (Kissinger) & 51 & 0 & 0 & 51 & Mega-Mexico & MEXICO (D.F., Hgo., Pue) \\
\hline Sayapion terale (Kissinger) & 1 & 1 & 0 & 0 & Mega-Mexico & MEXICO (S.L.P., Tamps.) \\
\hline Trichapion consanguineum (Wagner) & 20 & 10 & 8 & 2 & Mega-Mexico & $\begin{array}{l}\text { MEXICO (Gro., Hgo., Mor., S.L.P., } \\
\text { Sin.); NIC. }\end{array}$ \\
\hline T. godmani (Wagner) & 15 & 0 & 0 & 15 & Mega-Mexico & $\begin{array}{l}\text { USA (TX, AZ); MEXICO (Coah.; } \\
\text { D.F., Gro., Hgo., Pue., Mex., Mich., }\end{array}$ \\
\hline T. gracilirostre (Sharp) & 2 & 0 & 2 & 0 & Mega-Mexico & $\begin{array}{l}\text { Son. Ver.); GUAT, HOND. } \\
\text { MEXICO (Gro., Hgo., Pue., Mich.); } \\
\text { GUAT.; HOND. }\end{array}$ \\
\hline T. hadromerum (Wagner) & 1 & 0 & 0 & 1 & Mega-Mexico & $\begin{array}{l}\text { MEXICO (D.F., Dgo., Mich., Mor., } \\
\text { Hgo.,Sin.); GUAT. }\end{array}$ \\
\hline T. innocens (Kissinger) & 9 & 7 & 2 & 0 & Mega-Mexico & MEXICO (Hgo., S.L.P.) \\
\hline T. lassum (Sharp) & 23 & 5 & 17 & 1 & Tropical & $\begin{array}{l}\text { MEXICO (Pue., S.L.P., Ver.); GUAT.; } \\
\text { PAN. }\end{array}$ \\
\hline T. macropus (Wagner) & 1 & 1 & 0 & 0 & Mega-Mexico & $\begin{array}{l}\text { MEXICO (Chis., Gro., S.L.P.); } \\
\text { GUAT.; EL SALV. }\end{array}$ \\
\hline T. modicum (Kissinger) & 7 & 7 & 0 & 0 & Temperate & USA (IL, AZ, CO, MB, NE, WI) \\
\hline T. murinum (Gerstaecker) & 17 & 0 & 17 & 0 & Mega-Mexico & MEXICO (Gro., Hgo., Mor., Pue.) \\
\hline T. occiduum (Kissinger) & 4 & 0 & 0 & 4 & Mega-Mexico & USA (AZ); MEXICO (Tamps.) \\
\hline T. oscillator (Sharp) & 25 & 25 & 0 & 0 & Mega-Mexico & MEXICO (Tab.); Guat. \\
\hline T. plectrocolum (Kissinger) & 1 & 0 & 1 & 0 & Mega-Mexico & MEXICO (D.F.) \\
\hline T. proclive (LeConte) & 20 & 0 & 0 & 20 & Temperate & $\begin{array}{l}\text { CANADA; USA (AZ, BJ, CA, } \\
\text { NM, BC, ID, NV,OR, UT, WA, CO, } \\
\text { MT,WY); MEXICO (B.C., Dgo., } \\
\text { Mex., Pue.) }\end{array}$ \\
\hline T. quicorne (Kissinger) & 1 & 0 & 0 & 1 & Mega-Mexico & MEXICO (D.F., Pue., Mich.) \\
\hline T. rufipenne (Gyllenhal) & 34 & 33 & 1 & 0 & Tropical & $\begin{array}{l}\text { MEXICO (Gro., S.L.P., Tab., Ver.); } \\
\text { GUAT.; BEL.; COLOM.; VEN. }\end{array}$ \\
\hline T. submetallicum (Boheman) & 7 & 0 & 1 & 6 & Mega-Mexico & $\begin{array}{l}\text { USA (TX, AZ); MEXICO.(D.F., } \\
\text { Dgo., Gro., Hgo., Pue, Mex., Mor.) }\end{array}$ \\
\hline Trichapion sp. 1 & 1 & 1 & 0 & 0 & - & - \\
\hline Trichapion sp. 2 & 3 & 3 & 0 & 0 & - & - \\
\hline Trichapion sp. 3 & 4 & 4 & 0 & 0 & - & - \\
\hline \multicolumn{7}{|l|}{ Incertae sedis } \\
\hline 'Apion' disparipes Fall & 1 & 0 & 0 & 1 & Mega-Mexico & $\begin{array}{l}\text { USA (AZ,NM, TX); MEXICO } \\
\text { (D.F., Dgo., Gro., Jal., Mex., } \\
\text { Mor., Pue., Son.) }\end{array}$ \\
\hline 'Apion' disparatum Sharp & 4 & 4 & 0 & 0 & Temperate & $\begin{array}{l}\text { CANADA (AB, MB,); USA: (AZ, } \\
\text { CA, NM, TX, ND); MEXICO (Dgo., } \\
\text { Jal., Mor., Nay., Pue., Son.); GUAT. }\end{array}$ \\
\hline 'Apion' pauper Sharp & 2 & 2 & 0 & 0 & Tropical & $\begin{array}{l}\text { MEXICO (Mich., Mor., Nay., Pue., } \\
\text { Ver.); GUAT.; EL SALV.; PAN. }\end{array}$ \\
\hline 'Apion'seminudum Wagner & 5 & 5 & 0 & 0 & Tropical & $\begin{array}{l}\text { MEXICO (S.L.P., Tamps., Ver.); } \\
\text { GUAT.; EL SALV.; HOND.; PAN. }\end{array}$ \\
\hline Stenapion colle (Kissinger) & 4 & 2 & 2 & 0 & Mega-Mexico & MEXICO (Tamps.) \\
\hline TOTAL & 571 & 249 & 142 & 180 & & \\
\hline
\end{tabular}

